\title{
Peran BUMDes Dalam Upaya Membangun Kerukunan Umat di Desa Kuwaron Kecamatan Gubug Kabupaten Grobogan
}

Oleh :

\author{
Alda Gemellina Munadhiroh*1, Siti Halimah², Nikmatul Karimah \\ ${ }^{1,2,3}$ Pesantren Riset Al - Muhtada, Jalan Kol Hadijanto Nomor 117 Banaran Sekaran, \\ Gunung Pati, Kota Semarang 50229 \\ e-mail: *1 alda.gemellinam@ @ students.unnes.ac.id, ${ }^{2}$ Siha201001@ @students.unnes.ac.id , \\ 3nikmatulkarimah1128@students.unnes.ac.id
}

\begin{abstract}
Abstrak
Indonesia dikaruniai sebagai negara yang sangat majemuk, dengan pluralitas yang tinggi termasuk bidang agamanya. Akan tetapi pada pelaksanaannya heterogenitas tersebut justru menjadi alasan untuk saling menyerang dan menyakiti antar sesama. Tercatat masih banyak kasus berlabel agama. Hal tersebut menunjukkan kurangnya perhatian setiap elemen masyarakat dalam membangun dan menjaga kerukunan umat beragama di Indonesia. Salah satu elemen masyarakat yang ada di desa adalah BUMDes (badan usaha milik desa) yang salah satunya berada di Desa Kuwaron, Kecamatan Gubug, Kabupaten Grobogan dengan nama BUMDes Kuwariron Jaya. Desa Kuwaron sendiri termasuk ke dalam desa yang cukup heterogen dalam aspek agamanya. Oleh karena itu dalam penelitian ini dibahas mengenai peran BUMDes Kuwariron Jaya dalam membangun kerukunan umat beragama di Desa Kuwaron, serta hambatan yang ditemui dalam pelaksanaannya dan solusi yang tepat untuk mengatasinya. Penelitian dilakukan dengan mewawancarai direktur dari BUMDes Kuwariron Jaya dilengkapi dengan dokumen pendukung dari BUMDes Kuwariron Jaya. Dari penelitian ini diperoleh bahwa BUMDes dapat ikut berperan dalam membangun kerukunan umat beragama. Karena BUMDes merupakan lembaga yang bergerak di bidang ekonomi, maka peran BUMDes dalam membangun kerukunan umat beragama ialah melalui bidang ekonomi, dengan implementasi program - program kerja yang dapat membangun kerukunan umat beragama. BUMDes Kuwariron Jaya memiliki beberapa program kerja yang terkait diantaranya program pengelolaan sampah terpadu, program MBKJ (mitra bumdes kuwariron jaya), dan program lain yang dapat menunmbuhkan rasa kerukunan diantara masyarakat. BUMDes juga berperan sebagai informational role yang menjembatani anatara pemerintah dengan masyarakat. Penelitian ini menunjukkan bahwa BUMDes sebagai salah satu elemen desa juga memiliki andil dalam membangun kerukunan beragama.
\end{abstract}

Kata kunci:BUMDes, Kerukunan, Agama

PENDAHULUAN

Indonesia merupakan negara dengan masyarakat yang heterogen, dari aspek agama, ekonomi, budaya, hingga kekayaan alamnya. Hal tersebut menjadikan Indonesia sebagai negara majemuk yang sarat akan pluralitasnya. Pluralitas dalam hal agama di Indonesia telah diatur dan bahkan dilindungi dalam landasan konstitusional yakni Undang

Jurnal Ilmiah Al QALAM, Vol. 15, No. 2, Juli-Desember 2021 
Alda Gemellina Munadhiroh, Siti Halimah, Nikmatul Karimah : Peran BUMDes Dalam Upaya Membangun Kerukunan Umat di Desa Kuwaron Kecamatan Gubug Kabupaten Grobogan

- Undang, serta sejalan dengan sila pertama pancasila yang berbunyi "Ketuhanan Yang Maha Esa". Hal tersebut menunjukkan bahwa founding fathers Indonesia pada saat merumuskan dasar negara, telah memperhatikan pentingnya menjaga kesatuan terutama bagi umat beragama. Seperti yang tercantum dalam Undang-Undang Dasar 1945 terdapat Pasal 29 ayat (1) dan ayat (2) yang menyatakan bahwa, "Negara berdasar atas Ketuhanan Yang Maha Esa". Negara menjamin kemerdekaan tiap-tiap penduduk untuk memeluk agamanya masing-masing dan untuk beribadat menurut agama dan kepercayaannya. ${ }^{1}$

Akan tetapi disisi lain, konflik - konflik baik antar maupun intern umat beragama kenyataannya tidak dapat dibantahkan. Bahkan hingga saat ini masih banyak terjadi di Indonesia. Konflik sosial berbau agama di Indonesia dapat disebabkan oleh beberapa hal diantaranya :Pertama, adanya klaim kebenaran. Pluralitas manusia mengakibatkan interpretasi kebenaran yang berbeda - beda dan pemahaman yang absolut. Pemahaman demikian akan berpotensi konflik apabila dijadikan sebagai landasanpergerakan dalam berdakwah. Absolutisme, eksklusivisme, fanatisme, bahkan ekstremisme dan agresivisme adalah penyakit-penyakit yang dapat dengan mudah menghinggapi aktivis gerakan keagamaan. Absolutisme yaitu kesombongan intelektual, eksklusivisme yaitu kesombongan sosial, fanatisme yaitu kesombongan emosional, ekstremisme yaitu berlebih-lebihan dalam bersikap dan agresivisme yaitu berlebih-lebihan dalam melakukan tindakan fisik.Kedua, yaitu wilayah agama dan suku yang semakin kabur. Ketiga, adanya doktrin jihad yang dipahami secara sempit oleh para pemeluk agama atau kepercayaan. Keempat, sikap toleransi dalam beragama yang kian berkurang. Kelima, minimnya pemahaman terkait ideologi pluralism oleh masyarakat. ${ }^{2}$

Dilansir dari Tempo.co, Jakarta, direktur lembaga penelitian Setara Institute, Hailli menyatakan bahwa tercatat selama 12 tahun terakhir ini telah terjadi sebanyak 2.400 peristiwa pelanggaran kebebasan beragama dan berkeyakinan. Dalam hal ini Jawa Barat menempati posisi pertama, diikuti oleh DKI Jakarta di posisi kedua, dan Jawa Timur menduduki posisi ke tiga. Pelanggaran ini dilakukan oleh aktor negara maupun aktor non-negara rentang 5 tahun terakhir, Pemda menempati posisi tertinggi dengan jumlah 151 tindakan. Sedangkan untuk aktor non-negara, pelanggaran didominasi oleh kelompok warga dengan kasus mencapai 600 tindakan pelanggaran. Kemudian oleh ormas sebanyak 249 tindakan, MUI 242 tindakan, dan FPI 181 tindakan. Untuk pelanggaran KBB data riset menunjukkan adanya dominasi terhadap gangguan rumah ibadah. Dengan gereja menempati posisi pertama yaitu 199 gangguan. Sedangkan, gangguan terhadap masjid berada di angka 133. Kasus yang lain yaitu, rumah ibadah kepercayaan 32, vihara 15, klenteng 10, pura 8 gangguan dan 1 gangguan di sinagog. Sehingga totalnya mencapai 398 gangguan rumah ibadah. ${ }^{3}$

Salah satu lembaga desa yang sangat dekat dengan kehidupan masyarakat adalah Badan Usaha Milik Desa (BUMDes). BUMDes merupakan suatu lembaga/badan

\footnotetext{
${ }^{1}$ Lestari, Julita.2020.Pluralisme Agama Di Indonesia Tantangan dan Peluang Bagi Keutuhan Bangsa.Al-Adyan: Journal of Religious Studies, Volume 1, Nomor 1, 29- 38.

2 Aisyah BM, St.2014.Konflik Sosial Dalam Hubungan Antar Umat Beragama.Jurnal Dakwah Tabligh, Vol. 15, No. 2, 189- 208.

${ }^{3}$ Persada.2020.Setara Ada $2.400 \quad$ Insiden Pelanggaran Umat Beragama.https://nasional.tempo.co/read/1271038/setara-ada-2-400-insiden-pelanggaran-kebebasanberagama/full\&view=ok. Diakses pada Minggu, 13 Desember 2020
}

Jurnal Ilmiah Al QALAM, Vol. 15, No. 2, Juli-Desember 2021 
Alda Gemellina Munadhiroh, Siti Halimah, Nikmatul Karimah : Peran BUMDes Dalam Upaya Membangun Kerukunan Umat di Desa Kuwaron Kecamatan Gubug Kabupaten Grobogan

perekonomian desa yang berbadan hukum dibentuk dan dimiliki oleh Pemerintah Desa, dikelola secara ekonomis mandiri dan profesional dengan modal seluruhnya atau sebagian besar merupakan kekayaan desa yang dipisahkan. Oleh karena itu tujuan dibentuknya BUMDes adalah memperoleh keuntungan untuk memperkuat Pendapatan Asli Desa (PADes), memajukan perekonomian desa, dan meningkatkan kesejahteraan masyarakat desa.Pengaturan BUMDes tercantum dalam Undang - Undang Pasal 213 ayat (1) UU No. 32 Tahun 2004, bahwa Desa dapat mendirikan Badan Usaha Milik Desa sesuai dengan kebutuhan dan potensi desa. ${ }^{4}$

Sesuai dengan peraturan Bupati Grobogan Nomor 45 Tahun 2015 bahwa desa dapat mendirikan Badan Usaha Milik Desa berdasarkan peraturan desa tentang pendirian BUMDes $^{5}$, maka Desa Kuwaron menjadi salah satu desa di Kecamatan Gubug, Kabupaten Grobogan yang memiliki lembaga badan usaha milik desa (BUMDes) yang hingga kini dikenal dengan nama BUMDes Kuwariron Jaya. Dilihat dari penduduknya, Desa Kuwaron adalah salah satu desa yang berkembang cukup pesat menuju kota di Kecamatan Gubug, Kab. Grobogan. Hal ini dapat dilihat dari perkembangan kepadatan penduduk yang sudah mencapai 2806 (dua ribu delapan ratus enam) Kepala Keluarga (KK) yang tersebar di 9 (Sembilan) RW dan 35 RT. Dari aspek keberagaman umat beragama, desa kuwaron relatif heterogen. Ditandai dengan adanya rumah ibadah seperti masjid, gereja, dan juga klenteng. Selain itu di Desa Kuwaron juga terdapat dua organisasi dakwah islam terbesar di Indonesia yaitu Muhammadiyah dan Nahdhatul Ulama (NU). Keduanya berkembang cukup luas di Desa Kuwaron.

Adapun beberapa penelitian yang telah dilakukan sebelumnya yaitu, oleh Amelia Sri dan Kusuma Dewi (2014) dalam artikel yang berjudul Peranan Badan Usaha Milik Desa (Bumdes) Sebagai Upaya Dalam Meningkatkan Pendapatan Asli Desa (Pades) Serta Menumbuhkan Perekonomian Desa ${ }^{6}$. Artikel tersebut mengkaji tentang upaya yang dilakukan BUMDes dalam meningkatkan Pendapatan Asli Desa dan perannya dalam menumbuhkan perekonomian desa. Penelitian lainnya oleh Ifan Nursetiawan (2018) dalam artikel yang berjudul Strategi Pengembangan Desa Mandiri Melalui Inovasi BUMDes. $^{7}$ Artikel tersebut mengkaji tentang inovasi dari BUMDes sebagai upaya mewujudkan desa mandiri.

Berbeda dengan kajian - kajian sebelumnya, Artikel ini bermaksud mengkaji peran BUMDes dalam upaya membangun kerukunan umat Beragama oleh Bumdes Kuwariron Jaya, Desa Kuwaron, Kecamatan Gubug, Kabupaten Grobogan.

\section{METODE PENELITIAN}

Pada penelitian tentang peran BUMDES Kuwariron Jaya dalam upaya membangun kerukunan umat beragama ini, pendekatan yang digunakan menggunakan pendekatan penelitian kualitatif. Pada pendekatan ini dibahas pandangan secara filsafati

\footnotetext{
${ }^{4}$ Dewi, Amelia Sri Kusuma.2014.Peranan Badan Usaha Milik Desa (BUMDES) Sebagai Upaya Dalam Meningkatkan Pendapatan Asli Desa (PADES) Serta Menumbuhkan Perekonomian Desa.Journal of Rural and Development, Volume V No. 1, 1- 14.

${ }^{6}$ Sri Kusuma.2014.Peranan Badan Usaha Milik Desa (BUMDes) Sebagai Upaya. 1 - 14

7 Setiawan, Nur Irfan. 2018. Strategi Pengembangan Desa Mandiri Melalui Inovasi Bumdes. Jurnal Ilmiah Ilmu Pemerintahan ., 72- 81.
}

Jurnal Ilmiah Al QALAM, Vol. 15, No. 2, Juli-Desember 2021 
Alda Gemellina Munadhiroh, Siti Halimah, Nikmatul Karimah : Peran BUMDes Dalam Upaya Membangun Kerukunan Umat di Desa Kuwaron Kecamatan Gubug Kabupaten Grobogan

dari suatu penelitian mengenai disciplined inquary dan realitas dari subjek penelitian dalam kebiasaan penelitian ilmu-ilmu sosial termasuk penelitian pendidikan dan agama ${ }^{8}$. Paradigma kualitatif mencanangkan pendekatan yang humanistik untuk memahami suatu realitas sosial para idealis, memberikan tekanan pada pandangan terbuka tentang kehidupan sosial. Karena kehidupan sosial dipandang sebagai kreativitas bersama individu-individu, sehingga selanjutnya dunia sosial dianggap tidaklah tetap atau statis melainkan berubah dan dinamis.

Jenis penelitian pada penelitian ini, menggunakan penelitian deskriptif. Jenis penelitian tersebut merupakan suatu bentuk penelitian yang ditujukan untuk mendeskripsikan fenomena-fenomena yang ada, baik fenomena alamiah maupun fenomena buatan manusia. Fenomena tersebut dapat berupa bentuk, aktivitas, karakteristik, perubahan, hubungan, kesamaan, maupun perbedaan antara fenomena yang satu dengan fenomena lainnya ${ }^{9}$. Selain itu Furchan (2004:447) dalam bukunya menjelaskan bahwa penelitian deskriptif adalah penelitian yang dirancang untuk memperoleh informasi tentang status suatu gejala saat penelitian dilakukan ${ }^{10}$.

Adapun yang menjadi fokus pada penelitian ini adalah peran dari Badan Usaha Milik Desa (BUMDES) Kuwariron Jaya dalam upaya membangun kerukunan umat beragama, serta tantangan dan hambatan yang ditemui dalam melaksanakan peran tersebut. Penelitian ini berlokasi di Badan Usaha Milik Desa (BUMDES) Kuwariron Jaya, Desa Kuwaron, Kecamatan Gubug, Kabupaten Grobogan. Lokasi tersebut dipilih karena Desa Kuwaron merupakan salah satu desa yang berkembang cukup pesat menuju kota di Kecamatan Gubug, Kab. Grobogan. Hal ini terlihat dari perkembangan kepadatan penduduk yang sudah mencapai 2806 (dua ribu delapan ratus enam) Kepala Keluarga (KK) yang tersebar di 9 (Sembilan) RW dan 35 RT. Dengan kondisi masyarakatnya yang heterogen dari segi umat beragama, ditandai dengan adanya berbagai macam rumah ibadah, seperti masjid, gereja, dan rumah ibadah klenteng.

Pada penelitian ini, menggunakan dua jenis sumber data yakni sumber data primer dan sumber data sekunder. Sumber data primer yaitu sumber data penelitian yang diperoleh secara langsung dari sumber aslinya yang berupa wawancara, jajak pendapat dari individu atau kelompok (orang) maupun hasil observasi dari suatu obyek, kejadian atau hasil pengujian (benda). Kemudian yang kedua adalah sumber data sekunder. Sumber data sekunder adalah sumber data yang didapat melalui berbagai sumber yaitu literatur artikel, serta situs di internet yang berkenaan dengan penelitian yang dilakukan.

Tempat penelitian merupakan sasaran ilmiah untuk mendapatkan data dengan tujuan dan kegunaan tertentu tentang sesuatu hal yang objektif ${ }^{11}$. Kemudian untuk memperoleh data yang objektif yang diperlukan dalam penelitian, terlebih dahulu

\footnotetext{
${ }^{8}$ Subadi, Tjipto.2006.Metode Penelitian Kualitatif. Surakarta : Muhammadiyah University Press

${ }^{9}$ Linawarti,Mega.dkk.2016.Studi Deskriptif Pelatihan Dan Pengembangan SumberdayaManusia Serta Penggunaan Metode Behavioral Event Interview Dalam Merekrut Karyawan Baru Di Bank Mega Cabang Kudus.Journal Of Management Vol.2 No.2 1- 8.

${ }^{10}$ Ahmad Furchan, 2004. Pengantar Penelitian Dalam Pendidikan. Yogyakarta : Pustaka Belajar ${ }^{11}$ Sugiyono.2017. Pengaruh Lingkungan Kerja Non Fisik Dan Komunikasi Terhadap Kinerja Karyawan Pada PT. Bangkit Maju Bersama Di Jakarta. Jurnal Ilmiah, Manajemen Sumber Daya Manusia 419- 435
}

Jurnal Ilmiah Al QALAM, Vol. 15, No. 2, Juli-Desember 2021 
Alda Gemellina Munadhiroh, Siti Halimah, Nikmatul Karimah : Peran BUMDes Dalam Upaya Membangun Kerukunan Umat di Desa Kuwaron Kecamatan Gubug Kabupaten Grobogan

memahami bentuk penelitian serta beberapa teknik pengumpulan data yang digunakan. Dalam penelitian ini menggunakan dua bentuk penelitian, yang pertama adalah penelitian kepustakaan (Penelitian yang dilakukan dengan cara mempelajari literatur, diktat, jurnaljurnal, serta bahan-bahan yang berhubungan dengan topik penulisan), dan juga penelitian lapangan (Penelitian yang dilakukan secara langsung pada perusahaan untuk mendapatkan informasi yang realistis dengan cara wawancara, pengamatan/observasi, dan dokumentasi).

Pada penelitian ini, data yang akan dianalisis yaitu data yang diperoleh dari hasil observasi, wawancara menggunakan analisis asosiatif. Penelitian asosiatif adalah suatu pertanyaan penelitian yang bersifat menanyakan hubungan antara dua variabel atau lebih ${ }^{12}$. Analisis sosiatif yaitu penelitian dengan mengumpulkan data yang berupa wawancara, jajak pendapat dari individu atau kelompok (orang) maupun hasil observasi dari penelitian ini yang dibandingkan dengan jurnal atau literaturliteratur yang ada. Dan kemudian dianalisis berdasarkan teori yang ada.

\section{HASIL DAN PEMBAHASAN}

\subsection{Gambaran umum BUMDes Kuwariron Jaya}

BUMDes Kuwariron jaya merupakan badan usaha milik desa yang berdiri sejak tahun 2017 dengan nama BUMDes Tirta Makmur. Pergantian nama terjadi pada saat musyawarah desa berlangsung yaitu pada tanggal 08 Oktober 2019 dengan dihadiri 86 peserta yang terdiri dari BPD, PKK, Karang taruna, dan lembaga desa lainnya, serta pengurus RT dan RW. Nama Kuwariron berasal dari bahasa arab "kuwariro" yang artinya "kaca brenggala" atau suri tauladan. Nama tersebut dipilih dengan harapan serta obsesi bahwa BUMDes Kuwariron Jaya dapat menjadi teladan bagi BUMDes lain di Kecamatan Gubug maupun di Kabupaten Grobogan. Obsesi tersebut kemudian terbukti pada saat pertama kalinya BUMDes Kuwariron Jaya bergerak dengan melaunchingkan Mou antara bumdes dengan bulog pada tanggal 12 Desember 2019.

BUMDes Kuwariron Jaya terletak di Desa Kuwaron Kecamatan Gubug Kabupaten Grobogan. Disebelah utara berbatasan langsung dengan Kabupaten Demak, sebelah timur berbatasan dengan kecamatan Godong, Kecamatan Karangrayung, dan Kabupaten Demak. Sebelah Selatan berbatasan dengan Kecamatan Kedungjati dan Kecamatan Tanggungharjo, dan sebelah barat berbatasan dengan Kecamatan Tanggungharjo dan Kecamatan Tegowanu. Desa Kuwaron berada di kabupaten Grobogan, secara geografis Grobogan terletak di antara $110^{\circ} 15^{\prime}$ BT $111^{\circ} 25^{\prime} \mathrm{BT}$ dan $7^{\circ} \mathrm{LS}-7^{\circ} 30^{\prime} \mathrm{LS}$ dengan daerah pegunungan kapur serta perbukitan yang di tengahnya berupa dataran. ${ }^{13}$

BUMDes Kuwariron Jaya berdiri ditengah kondisi masyarakat Desa Kuwaron yang cukup heterogen. Berdasarkan data dari sidesa Dispermadesdukcapil Prov.Jateng ${ }^{14}$, penduduk di desa Kuwaron yaitu sebanyak $4.54 \mathrm{Rb}$ berjenis kelamin

${ }^{12}$ Sugiyono.2018. Pengaruh Motivasi, Kepercayaan dan Sikap Konsumen Terhadap Minat Beli Pengguna Online Shop Zalora Pada Mahasiswa Fakultas Ekonomi dan Bisnis UNSRAT Manado. Jurnal EMBA.Vol.7 No.4Oktober 2019, Hal. 5693-5702

${ }^{13}$ AD-ART BUMDes Kuwariron Jaya

${ }^{14}$ Dispermadesdukcapil Prov. Jateng

Jurnal Ilmiah Al QALAM, Vol. 15, No. 2, Juli-Desember 2021 
Alda Gemellina Munadhiroh, Siti Halimah, Nikmatul Karimah : Peran BUMDes Dalam Upaya Membangun Kerukunan Umat di Desa Kuwaron Kecamatan Gubug Kabupaten Grobogan

pria dan sebanyak $4.57 \mathrm{Rb}$ berjenis kelamin wanita. Masyarakat desa Kuwaron memiliki aliran kepercayaan atau agama yang dianut yaitu agama budha sebanyak 3 jiwa, katholik sebanyak 65 jiwa, agama kristen sebanyak 56 jiwa dan agama islam sebanyak 8.980 jiwa. Pekerjaan masyarakat desa Kuwaron juga sangat beragam. Dari data yang tercatat sebanyak 1.325 jiwa memiliki pekerjaan sebagai PNS, pensiunan sebanyak 1.041 jiwa, sebagai TNI sebanyak 17 jiwa, PORLI sebanyak 85 jiwa, sebagai petani 10 jiwa, sebagai pedagang sebanyak 215 jiwa, sebagai ibu rumah tangga sebanyak 96 jiwa, dan sebanyak 1.691 jiwa berprofesi sebagai pelajar atau mahasiswa.

Dalam pelaksanaannya BUMDes Kuwariron Jaya terbagi menjadi beberapa divisi atau usaha. pertama yaitu divisi pengelolaan sampah dan parkir, kedua yaitu diklat dan pengelolaan tenaga kerja, yang ketiga pengelolaan pertanian, peternakan dan perdagangan umum termasuk didalamnya adalah sembako. Keempat, yaitu divisi konstruksi dan jasa. Divisi pengelolaan sampah berkerja sama dengan dinas lingkungan hidup dalam pengelolaan sampah rumah tangga masyarakat di Desa Kuwaron. Divisi ini memiliki program bernama "Bank Sampah" yang nantinya hasil pengolahan sampah tersebut kan dijadikan sebagai pupuk organik dan pakan ternak.

Divisi selanjutnya adalah divisi pengelolaan hasil pertaniana, peternakan, dan perdagangan umum termasuk sembako. Pada divisi tersebut terdapat beberapa program kerja berupa kerja sama antara BUMDes Kuwariron Jaya dengan pihak swasta dan BUMN seperti Bulog, Kantor Pos Indonesia, dan bank BRI. Selain itu terdapat program yang merupakan bentuk kerja sama dari BUMDes dengan pedagang - pedagang kecil di Desa Kuwaron yaitu program "MBKJ" atau Mitra BUMDes Kuwariron Jaya. Divisi selanjutnya yaitu Pengelolaan Tenaga kerja, Diklat dan Penyaluran Tenaga Kerja. Berfungsi menangani masyarakat usia kerja maupun pra kerja di Desa Kuwaron yang telah bekerja maupun yang belum mendapatkan pekerjaan sehingga lebih terkoordinir dan menjadi salah satu solusi dalam mengurangi angka pengangguran di Desa Kuwaron. Divisi terakhir yaitu divisi konstruksi dan jasa. Divisi ini masih dalam pencanangan dengan rencana kedepan BUMDes akan membuat CV. Sehingga harapannya BUMDes dapat go publik dan tidak hanya bersibuk di desa.

3.2 Peran BUMDes Kuwariron Jaya dalam upaya membangun kerukunan umat beragama di Desa Kuwaron Kecamatan Gubug Kabupaten Grobogan

Kerukunan dan toleransi dapat dibangun dalam berbagai cara. Diantaranya melalui pendidikan baik formal maupun non formal, bisa juga dari kegiatan kegiatan sosial, maupun dari kegiatan ekonomi. Bumdes pada dasarnya memiliki cakupan yang luas dari pendidikan, dan gerakan ekonomi. Sebab bumdes merupakan badan usaha yang harus bertujuan profit namun tidak dapat meninggalkan kerja - kerja sosial. Diantara lembaga - lembaga desa yang ada mayoritas berada pada tatanan sosial. Berbeda dengan BUMDes, yang harus menjalankan nilai - nilai sosialnya namun tetap bernilai profit atau keuntungan. Direktur BUMDes Kuwariron Jaya, Drs. Sadzali, S.Ag mengatakan bahwa peran BUMDes dalam membangun kerukunan umat ialah melalui implementasi dari setiap program kerja yang disusunnya.

Setiap desa memiliki lembaga agama lengkap dengan lembaga dakwah atau misionarisnya masing - masing. Jika lembaga dakwah membangun kerukunan umat

Jurnal Ilmiah Al QALAM, Vol. 15, No. 2, Juli-Desember 2021 
Alda Gemellina Munadhiroh, Siti Halimah, Nikmatul Karimah : Peran BUMDes Dalam Upaya Membangun Kerukunan Umat di Desa Kuwaron Kecamatan Gubug Kabupaten Grobogan

melalui pendidikan, teori, ataupun kajian dan ta'lim, maka bumdes mengambil celah lain yaitu dalam bidang ekonomi melalui kegiatan - kegiatan ekonominya.

Upaya membangun kerukunan umat beragama oleh BUMDes Kuwariron Jaya tergantung bagaimana realisasi program - program kerjanya. Sebagai contoh yaitu persoalan sampah. Semua agama tentu mengajarkan untuk peduli pada sampah. Pak RT yang awalnya kurang peduli, menjadi ikut berperan aktif dalam melakukan pendataan kegatan bergerak secara sporadis atau bersama menjadi tanggungjwaba semua bukan hanya bumdes. Sehingga masyarakat mulai sadar pentingnya peduli, sehingga ketika ada masyarakat yang membuang sampah sembarangan, bukan bumdes yang memberi sanki ataupun desa melainkan masyarakat itu sendiri. Desa hanya mengeluarkan perdes tentang sampah tersebut. di dalamnya mengatur mengenai masyarakat yang melanggar akan mendapat teguran dan sanksi. Dengan adanya perdes tersebut, yang sebelunya desa tidak dapat menindak lanjuti para pelanggar, kini dapat bertindak lebih tegas karena bumdes telah menyediakan tempat bagi pengelolaan sampah tersebut. sehingga nantinya jika ada masyarakat yang melanggar maka dari RT/RW dan masyarakat sendiri yang akan saling mengingatkan. Hal tersebut menjadi salah satu contoh kerukunan yang secara tidak langsung dibangun melalui program pengelolaan sampah.

Contoh kedua yaitu pada program MBKJ (mitra BUMDes Kuwariron Jaya). Sebelumnya orang - orang lebih memilih membeli kebutuhan pokok di pasar karena harga yang lebih murah atau di supermarket karena persepsi masyarakat yang dianggap lebih keren jika membeli di supermarket diabnding dengan toko tetangga. Hal tersebut kemudian menjadi bahan diskusi pengurus BUMDes dengan beberapa pemilik toko. Setelah berdiskusi kemudian diperoleh akar permasalahan bahwa kebanyakan masyarakat datang ke toko tetangga hanya untuk membeli kebutuhan pokok atau keperluan yang mememang mendesak saat itu juga. Sedangkan untuk keperluan lain dalam jumlah yang relatif lebih besar, masyarakat akan lari ke pasar sebab harga lebih murah. Sedangkan untuk toko - toko kecil tidak akan sanggup untuk menurunkan harga sebab harga beli para penjual di toko - toko tersebut juga sudah tinggi. Oleh karena itu bumdes hadir menawarkan solusi dengan memberikan modal berupa barang pada toko - toko tersebut dengan harga lebih murah, sehingga harga jual di toko - toko juga bisa lebih murah dan masyarakat tidak perlu repot untuk ke pasar dan memilih membeli di toko tetangga. Sehingga konsep yang dibangun dari program ini ialah bangga belanja di toko tetangga. Ketika masyarakat sudah bangga dan memilih untuk memberdayakan toko - toko tetangga, maka akan terjalin kerukunan di dalamnya. Hal tersebut sebagai salah satu upaya membangun kerukunan masyarakat melalui gerakan ekonomi. Berbicara perihal kerukunan itu dapat dibangun dalam berbagai cara dan bumdes mengambil cara lain yang tidak digunakan oleh lembaga atau badan - badan desa lainnya.

Oleh karena itu selain dari program kerjanya, BUMDes Kuwariron Jaya juga mengambil peran sebagai informational role dalam membangun kerukunan umat beragama. Yakni hadirnya BUMDes menjadi pemantau, diseminator, dan juru bicara yang melalui program - programnya dapat meningkatkan kepercayaan antar sesama masyarakat maupun antar masyarakat dengan pemerintah desa. Sehingga konflik antar umat dapat diredam dan menciptakan kerukunan di tengah masyarakat. Salah satu upaya lain yang dilakukan BUMDes Kuwariron Jaya dalam membangun kerukunan

Jurnal Ilmiah Al QALAM, Vol. 15, No. 2, Juli-Desember 2021 
Alda Gemellina Munadhiroh, Siti Halimah, Nikmatul Karimah : Peran BUMDes Dalam Upaya Membangun Kerukunan Umat di Desa Kuwaron Kecamatan Gubug Kabupaten Grobogan

adalah bekerjasama dengan pemerintah desa dalam membangun toleransi beragama, setelah berkomunikasi dengan pemerintah setempat, BUMDes Kuwariron Jaya mengadakan kegiatan salat Eid berjamaah saat Hari Raya Idul Adha 2020 lalu di sebuah lapangan yang bersebelahan dengan gereja terbesar di daerah tersebut. Hal ini dilakukan untuk menunjukkan pada masyarakat tentang pentingnya toleransi. Kegiatan tersebut mengindikasikan peran BUMDes sebagai juru bicara dan diseminator yakni penghubung antara pemerintah dan masyarakat dalam menciptakan kerukunan umat beragama.

3.3 Hambatan dan tantangan yang dihadapi dalam upaya membangun kerukunan umat beragama di Desa Kuwaron Kecamatan Gubug Kabupaten Grobogan.

Hambatan yang kerap dijumpai oleh BUMDes kuwariron jaya lebih kepada membangun kepercayaan masyarakat dan pemerintah dalam mencanangkan suatu program. Hal ini dikarenakan progja BUMDes ada yang melibatkan banyak pihak dan tanpa melibatkan banyak pihak. Untuk program yang tidak melibatkan banyak pihak tentu memiliki hambatan yang lebih sedikit. Namun untuk program yang melibatkan banyak pihak tentu cukup berat. Mulai dari menyamakan visi misi bagaimana memahamkan pengurus dan pemerintah desa sehingga dapat dibuatkan perdesnya, dan meyakinkan kemasyarakat.

Menurut hasil wawancara dengan direktur Bumdes Kuwariron Jaya sekaligus ketua forum komunikasi kecamatan gubug Drs. Sadzali, S.Ag, terdapat 6 catatan tantangan yang dihadapi oleh BUMDes - BUMDes di Kecamatan Gubug termasuk BUMDes Kuwariron Jaya diantaranya yaitu: kurangnya pemahaman terkait filosofi penddirian BUMDes, kurangnya sinergi antara pengurus BUMDes dengan pemerintah desa. Persoalan politik di desa yang cukup tinggi, dan pemilihan ketua BUMDes yang masih bergantung pada kepala desa saat itu. BUMDes tidak bisa menjadi oposisi kepala desa, namun juga tidak bisa bernaung dibawah kuasa kepala desa. Pengurus BUMDes harus memiliki independensi yang kuat dan tidak bergantung pada yang lain. selain itu terdapat kendala dalam mendapatkan modal usaha dari pemerintah desa. Kendala yang lain yaitu status hukum atau payung hukum dari perangkat yang dimiliki BUMDes dan pemilihan program kerja dari BUMDes

3.4 Solusi bagi BUMDes Kuwariron Jaya dalam upaya membangun kerukunan umat beragama di Desa Kuwaron Kecamatan Gubug Kabupaten Grobogan

Setiap program pasti ada hambatan. Oleh karenanya penting untuk menerapkan analisis SWOT (Strengths, Weaknesses, Opportunities, and Threats) yang matang, Supaya program dapat berjalan dengan baik. SWOT sendiri merupakan analisis yang digunakan untuk mengevaluasi peluang dan ancaman dilingkungan bisnis maupun kekuatan serta kelemahan yang dimiliki internal perusahaan. ${ }^{15}$ Oleh karena itu konsep yang dibangun pertama kali harus sangat matang. Pada program pengelolaan sampah membutuhkan waktu 1 tahun hanya untuk merancang konsep programnya. Lebih dari itu analisis SWOT dengan tepat sangat diperlukan. Dalam membangun kepercayaan dari masyarakat terkait semua program -program yang dicanangkan oleh bumdes, maka yang perlu dilakukan, pertama yaitu menyamakan pemahaman antar pengurus BUMDes Kuwariron Jaya.

15 Srinadi, Ni Luh Putri. 2016.Analisis SWOT sebagai Dasar Menentukan Strategi Pemasaran Kompetitif (Studi Kasus : Usaha Jasa Dekorasi X).Yogyakarta.Seminar Nasional Teknologi Informasi dan Komunikasi. Hal 09.

Jurnal Ilmiah Al QALAM, Vol. 15, No. 2, Juli-Desember 2021 
Alda Gemellina Munadhiroh, Siti Halimah, Nikmatul Karimah : Peran BUMDes Dalam Upaya Membangun Kerukunan Umat di Desa Kuwaron Kecamatan Gubug Kabupaten Grobogan

Selain itu perlu melakukan pendekatan baik secara personal maupun dalam bentuk sosialisasi untuk memberikan pemahaman bahwa BUMDes hadir di tengah masyarakat bukan untuk menguasa i atau bahkan menyaingi usaha masyarakat, akan tetapi BUMDes harus menjadi lokomotif diantara gerbong yang ada meskipun berat. Lokomotif tidak harus yang memiliki super power, melainkan memiliki gerakan, inovatif dan obsesi yang kuat untuk memotivasi yang lainnya. selama ini lokomotif haruslah yang super power dan bermodal besar sehingga dapat mengalahkan yang lainnya. oleh karena itu penting dalam mengatur strategi. Karena selagi proses masih berjalan, tantangan akan selalu ada.

Sebagai lembaga usaha, maka inovasi - inovasi juga perlu dilakukan secara kontinu, sehingga program - program yang telah dicanangkan dapat berjalan secara efektif dan efisien.

\section{KESIMPULAN}

Peran BUMDes Kuwariron Jaya dalam membangun kerukunan umat beragama dilakukan melalui implementasi program kerjanya. Diantara beberapa program kerja BUMDes yang dapat membangun kerukunan umat beragama yaitu ; prograam sembako murah menjelang Ramadhan yang ditujukan untuk seluruh masyarakat desa tanpa membedakan ras maupun agamanya. Selanjutnya yaitu program Mitra Bumdes Kuwariron Jaya (MBKJ) yaitu program untuk menggalakkan mindset "bangga belanja di toko tetangga”. Program ini bertujuan untuk meningkatkan kepedulian masyrakat terhadap sesama sehingga akan terjalin kerukunan didalamnya. Selain itu terdapat juga program sampah terpadu. Program ini meripakan program yang mengajak masyrakat dan pemerintah saling bekerjasama dan meningkatkan kepedulian terhadap lingkungan. BUMDes disini berperan sebagai fasilitator dan jembatan antara pemerintah dengan masyarakat sehingga tidak ada lagi konflik di tengah masyarakat.

Di luar dari program kerja yang telah dilaksanakan, BUMDes Kuwariron Jaya juga mengambil peran sebagai informational role dalam membangun kerukunan umat beragama. Yakni hadirnya BUMDes menjadi pemantau, diseminator, dan juru bicara yang melalui program - programnya dapat meningkatkan kepercayaan antar sesama masyarakat maupun antar masyarakat dengan pemerintah desa. Salah satu contohnya yakni dengan mengadakan kegiatan salat Eid berjamaah saat Hari Raya Idul Adha 2020 lalu di sebuah lapangan yang bersebelahan dengan gereja terbesar di daerah tersebut. Hal ini dilakukan untuk menunjukkan pada masyarakat tentang pentingnya toleransi beragama.

Kedua, dalam melakukan perannya, terdapat pula hambatan- hambatan yang kerap dijumpai oleh BUMDes kuwariron jaya, salah satunya adalah lebih kepada membangun kepercayaan masyarakat dan pemerintah dalam mencanangkan suatu program. Hal ini dikarenakan progja BUMDes ada yang melibatkan banyak pihak dan tanpa melibatkan banyak pihak. Untuk program yang tidak melibatkan banyak pihak tentu memiliki hambatan yang lebih sedikit. Namun untuk program yang melibatkan banyak pihak tentu cukup berat. Mulai dari menyamakan visi misi bagaimana memahamkan pengurus dan pemerintah desa sehingga dapat dibuatkan perdesnya, dan meyakinkan kemasyarakat. Menurut direktur Bumdes Kuwariron Jaya sekaligus ketua forum komunikasi kecamatan gubug, terdapat 6 catatan tantangan yang dihadapi oleh BUMDes - BUMDes di Kecamatan Gubug termasuk BUMDes Kuwariron Jaya diantaranya yaitu: kurangnya

Jurnal Ilmiah Al QALAM, Vol. 15, No. 2, Juli-Desember 2021 
Alda Gemellina Munadhiroh, Siti Halimah, Nikmatul Karimah : Peran BUMDes Dalam Upaya Membangun Kerukunan Umat di Desa Kuwaron Kecamatan Gubug Kabupaten Grobogan

pemahaman terkait filosofi penddirian BUMDes, kurangnya sinergi antara pengurus BUMDes dengan pemerintah desa. Persoalan politik di desa yang cukup tinggi, dan pemilihan ketua BUMDes yang masih bergantung pada kepala desa saat itu. BUMDes tidak bisa menjadi oposisi kepala desa, namun juga tidak bisa bernaung dibawah kuasa kepala desa. Pengurus BUMDes harus memiliki independensi yang kuat dan tidak bergantung pada yang lain. selain itu terdapat kendala dalam mendapatkan modal usaha dari pemerintah desa. Kendala yang lai yaitu status hukum atau payung hukum dari perangkat yang dimiliki BUMDes dan pemilihan program kerja dari BUMDes.

Ketiga, setiap program kerja pasti ada hambatan. Oleh karenanya penting untuk menerapkan analisis SWOT yang matang, Supaya program dapat berjalan dengan baik. Oleh karena itu konsep yang dibangun pertama kali harus sangat matang. Pada program pengelolaan sampah membutuhkan waktu 1 tahun hanya untuk merancang konsep programnya. Lebih dari itu analisis SWOT dengan tepat sangat diperlukan. Dalam membangun kepercayaan dari masyarakat terkait semua program -program yang dicanangkan oleh bumdes, maka yang perlu dilakukan, pertama yaitu menyamakan pemahaman antar pengurus BUMDes Kuwariron Jaya.

\section{SARAN dan REKOMENDASI}

Berdasarkan penelitian yang penulis lakukan, maka penulis memberikan masukan beberapa hal sebagai bahan pertimbangan agar nantinya Badan Usaha Milik Desa (BUMDes) dapat lebih berperan penting dalam masyarakat, baik dalam bidang ekonomi, pendidikan dan juga sosial. Adapun beberapa masukan dari penulis antara lain sebagai berikut :

Pertama yaitu pengoptimalan pelaksanaan program kerja BUMDes dan juga kegiatan- kegiatan yang dilakukan dengan masyarakat agar membuahkan hasil yang optimal pula. Kedua, memberikan edukasi atau pun sosialisasi kepada masyarakat yang masih awam dengan program kerja atau kegiatan- kegiatan dari BUMDes, agar semua elemen masyarakat dapat bekerja sama dan melaksanakan program kerja dengan baik. Ketiga memperkuat sinergi antara BUMDes Dengan pemerintah desa serta warga sekitar demi terwujudnya masyarakat sejahtera dan menjunjung tinggi kerukunan.

Tentunya pada penelitian yang penulis lakukan masih terdapat banyak kekurangan. Untuk itu, penulis berharap nantinya akan ada penelitian lain yang bisa menyempurnakan penelitian yang penulis lakukan.

\section{DAFTAR PUSTAKA}

Ahmad Furchan, 2004. Pengantar Penelitian Dalam Pendidikan. Yogyakarta : Pustaka Belajar

Aisyah BM, St.2014.Konflik Sosial Dalam Hubungan Antar Umat Beragama.Jurnal Dakwah Tabligh, Vol. 15, No. 2

Jurnal Ilmiah Al QALAM, Vol. 15, No. 2, Juli-Desember 2021 
Alda Gemellina Munadhiroh, Siti Halimah, Nikmatul Karimah : Peran BUMDes Dalam Upaya Membangun Kerukunan Umat di Desa Kuwaron Kecamatan Gubug Kabupaten Grobogan

Dewi, Amelia Sri Kusuma.2014.Peranan Badan Usaha Milik Desa (BUMDES) Sebagai Upaya Dalam Meningkatkan Pendapatan Asli Desa (PADES) Serta Menumbuhkan Perekonomian Desa.Journal of Rural and Development, Volume V No. 1

Lestari, Julita.2020.Pluralisme Agama Di Indonesia Tantangan dan Peluang Bagi Keutuhan Bangsa.Al-Adyan: Journal of Religious Studies, Volume 1, Nomor 1

Linawarti,Mega.dkk.2016.Studi Deskriptif Pelatihan Dan Pengembangan SumberdayaManusia Serta Penggunaan Metode Behavioral Event Interview Dalam Merekrut Karyawan Baru Di Bank Mega Cabang Kudus.Journal Of Management Vol.2 No.2.

Persada.2020.Setara Ada 2.400 Insiden Pelanggaran Umat Beragama.https://nasional.tempo.co/read/1271038/setara-ada-2-400-insidenpelanggaran-kebebasan-beragama/full\&view=ok. Diakses pada Minggu, 13 Desember 2020

Setiawan, Nur Irfan. 2018. Strategi Pengembangan Desa Mandiri Melalui Inovasi Bumdes. Jurnal Ilmiah Ilmu Pemerintahan .Vol 4, No 2

Srinadi, Ni Luh Putri. 2016.Analisis SWOT sebagai Dasar Menentukan Strategi Pemasaran Kompetitif (Studi Kasus : Usaha Jasa Dekorasi X).Yogyakarta.Seminar Nasional Teknologi Informasi dan Komunikasi.Hal.09

Subadi, Tjipto.2006.Metode Penelitian Kualitatif. Surakarta : Muhammadiyah University Press

Sugiyono.2017. Pengaruh Lingkungan Kerja Non Fisik Dan Komunikasi TerhadapKinerja Karyawan Pada PT. Bangkit Maju Bersama Di Jakarta. Jurnal Ilmiah, Manajemen Sumber Daya Manusia.

Sugiyono.2018. Pengaruh motivasi, kepercayaan dan sikap konsumen terhadap minat beli pengguna online shop Zalora pada mahasiswa fakultas ekonomi dan bisnis UNSRAT Manado. Jurnal EMBA.Vol.7 No.4Oktober 2019, Hal. 5693-5702

Jurnal Ilmiah Al QALAM, Vol. 15, No. 2, Juli-Desember 2021 